\title{
ANTIHYPERURICEMIC EFFECT OF RED GINGER POWDER AND LIME JUICE COMBINATION IN HYPERURICEMIA INDUCED WISTAR RATS
}

\author{
Eva Susanty Purba ${ }^{1}$, Chikita Dian Rahma Saphira ${ }^{1}$, Salma Yasmine Azzahara ${ }^{1}$, Edwin Basyar ${ }^{2}$, \\ Muflihatul Muniroh ${ }^{2}$, Ainun Rahmasari Gumay ${ }^{2 *}$ \\ ${ }^{1}$ Undergraduate Program, Faculty of Medicine, Diponegoro University, Semarang, Indonesia \\ ${ }^{2}$ Department of Physiology, Faculty of Medicine, Diponegoro University, Semarang, Indonesia \\ ${ }^{*}$ Corresponding author, E-mail: ainungumay@fk.undip.ac.id
}

\begin{abstract}
Background: Hyperuricemia is an abnormally high level of uric acid in the blood. Ginger and lime are natural ingredients that contain antioxidants and anti-inflammatory which could reduce blood uric acid levels. This study aims to prove the effect of red ginger powder and lime juice combination on uric acid levels of hyperuricemia induced wistar rats.Methods: Experimental research with pre and post test control group design. Thirty male wistar rats, aged 2-3 months, weighed 150-350 grams randomly divided into 5 groups. Group C1 was normal control group. Group $\mathrm{C} 2$ was induced by single intraperitoneal injection of potassium oxonate $(300 \mathrm{mg} / \mathrm{kgBW})$. Group T1, T2, T3 were induced by potassium oxonate and orally administered with combination of red ginger powder $(300,600,1200 \mathrm{mg} / 200 \mathrm{gBW})$ and lime juice $(2 \mathrm{ml} / 150 \mathrm{gBW})$. Blood samples in each group will be collected in 1 hour after treatment. Uric acid levels were measured using the TBHBA uric acid method. Results: Uric acid level in T1, T2, and T3 group was significantly lower than C2 group (p<0,05). The most effective dose to reduce uric acid levels was $1200 \mathrm{mg} / 200 \mathrm{gBW}$ red ginger in combination with 2ml/150gBW lime juice (T3 group). Conclusion: Red ginger powder and lime juice reduce the blood uric acid levels in hyperuricemia induced wistar rats.
\end{abstract}

Keywords: Hyperuricemia, red ginger, lime juice, potassium oxonate

\section{INTRODUCTION}

WHO 2016 stated that there was 47 million death caused by non-contagious diseases. It refers to a $70 \%$ mortality rate from 57 million world's death cases [1]. One of the non-contagious diseases that frequently happened in Indonesia is gout. In 2008, NHANES identified 3,9\% of adults (age $\geq 20$ years old) suffer from gout [2]. According to RISKESDAS 2018, in Indonesia, there were $7.3 \%$ cases of gout [3], and based on epidemiology survey in Central Java with WHO-COPCORD towards 4.683 sample (age 15-45 years old) shows that hyperuricemia prevalence are $24.4 \%$ in boys, $11.7 \%$ in girls, and $17.6 \%$ in both of gender [4].

Hyperuricemia means increasing of uric acid level in blood (above $7.7 \mathrm{mg} / \mathrm{dl}$ in man and above $6.6 \mathrm{mg} / \mathrm{dl}$ in woman). It caused by 2 main probabilities: the over production of uric acid or obstruction in uric acid excretion. Gout is a heterogeneous disease caused by deposition of monosodium urate crystals which are the final products of purine metabolism. [5]. The risk factors were age, gender, weight, high purines diet, physical activity, over consumption of alcohol, drugs and other diseases such as renal function disorder, hypertension, DM, dyslipidemia, etc [6].

Allopurinol is the drug of choice for gout. However, allopurinol can arise adverse effect like nausea, vomiting, diarrhea, renal disorder, hepatotoxicity and hypersensitivity [7]. Therefore, we need another alternative medicine to reduce the allopurinol's adverse effect. According to previous research, ginger contains anti-inflammatory and high antioxidant ingredients such as gingerol, shagaol, paradol, zingerone, flavonoid, polifenol, riboflavin, and vitamin that can reduce uric acid level $[8,9]$. We combine red ginger and lime juice to increase effectiveness within uric acid level reduction. Lime contains vitamin C and B1, citric acid 7\%, amino acid, essential oil (limonene), and bioflavonoid [10]. Vitamin $\mathrm{C}$ can inhibit uric acid reabsorption by kidney, then improve kidney work speed to excreting uric acid via urine [11]. 
Eva Susanty Purba, Chikita Rahma Saphira, Salma Azzahara,

Edwin Nasyar, Muflihatul Muniroh, Ainun Rahmasari Gumay

\section{METHODS}

This research is experimental reaserch with pre and post test control group design. Twenty-five male Wistar rats (Rattus norvegicus) aged 8-12 weeks, weighed 150-200 grams, healthy and active, randomly divided into 5 groups. Each group consists of 5 rats. Twenty rats carried out the induction of hyperuricemia with potassium oxonate. Exclusion criteria were inactive and sick rats during the experimental process. Rats were randomly divided into 5 groups, each consisted of 5 rats. Group I was the normal control group (C1). Group $\mathrm{C} 2$ was the negative control group which were administered with high purines diet and induced by 300 $\mathrm{mg} / \mathrm{kgBW}$ of potassium oxonate. Group T1, T2, T3 were induced by potassium oxonate and orally administered with combination of red ginger powder $(300,600,1200 \mathrm{mg} / 200 \mathrm{gBW})$ and lime juice $(2 \mathrm{ml} / 150 \mathrm{gBW})$ that has been mixed.

Fresh red ginger was washed and separated from the skin, cut, and dried. Dry ginger was blended till powdered, then filtered with sieved of 80 mesh. Fresh lime then was cleaned and cut into two pieces, squeeze out and filtered. Before treatments, all rats have been acclimated for 7 days. On the next day, each group were given treatment in accordance with the provisions. $\mathrm{C} 1$ was not induced by potassium oxonate. $\mathrm{C} 2, \mathrm{~T} 1, \mathrm{~T} 2$, and $\mathrm{T} 3$ was induced by $300 \mathrm{mg} / \mathrm{kgBW}$ of potassium oxonate, and after one hour, blood was collected through intraorbital puncture. Afterwards, $\mathrm{C} 1$ and $\mathrm{C} 2$ were treated only by food and drink. T1, T2, and T3 were administered with combination of red ginger powder with the dose of $300 \mathrm{mg} / 200 \mathrm{gBW}, \quad 600 \mathrm{mg} / 200 \mathrm{gBW}$, $1200 \mathrm{mg} / 200 \mathrm{gBW}$, and lime water with the dose of $2 \mathrm{ml} / 150 \mathrm{gBW}$. One hour later, blood was collected through intraorbital puncture to determine uric acid levels after administration of therapy. The serum measurement was done using Uric Acid TBHBA Method (2,4,6 tribromo-3-hydroxybenzoic acid) [12,13].

One-Way Analysis of Variance (ANOVA) and Kruskal-Wallis were used for statistical analysis, using SPSS version 24.0 for windows [14].

\section{RESULT}

The data was obtained from measurement of uric acid levels. Data analysis of pre and post test results can be seen in Figure 1.

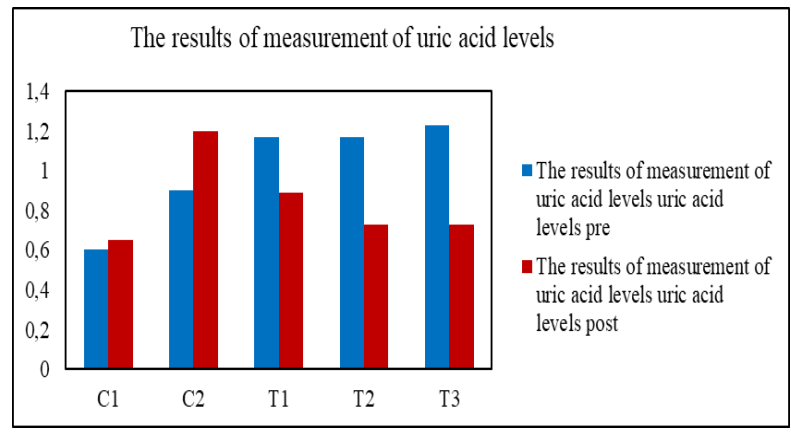

Figure 1. Pre and Post Test Result of Uric Acid Levels.

In Figure 1 it was shown that there is no difference between pre and post test result in the $\mathrm{C} 1$ group. One hour after potassium oxonate induction on $\mathrm{C} 2, \mathrm{~T} 1, \mathrm{~T} 2$, and $\mathrm{T} 3$ group showed an increase in uric acid levels. In T1, T2 and T3 group which were treated with red ginger powder and lime juice showed a decreased of uric acid levels.

Table 1. Standart Deviation Of Uric Acid

\begin{tabular}{lccc}
\hline \multirow{2}{*}{ Group } & \multicolumn{3}{c}{ Standart Deviation Of Uric Acid (mg/dl) } \\
\cline { 2 - 4 } & Pre & Post & Deviation Pre-Post \\
\hline C1 & $0.6 \pm 0.015$ & $0.64 \pm 0.49$ & $0.04 \pm 0.047$ \\
C2 & $0.9 \pm 0.058$ & $1.19 \pm 0.127$ & $0.29 \pm 0.093$ \\
T1 & $1.16 \pm 0.214$ & $0.88 \pm 0.07$ & $-0.27 \pm 0.181$ \\
T2 & $1.16 \pm 0.408$ & $0.73 \pm 0.114$ & $-0.43 \pm 0.317$ \\
T3 & $1.22 \pm 0.167$ & $0.73 \pm 0.214$ & $-0.49 \pm 0.299$ \\
\hline
\end{tabular}

Analysis of the mean difference in prepost data can be seen in Figure 2. 
Eva Susanty Purba, Chikita Rahma Saphira, Salma Azzahara,

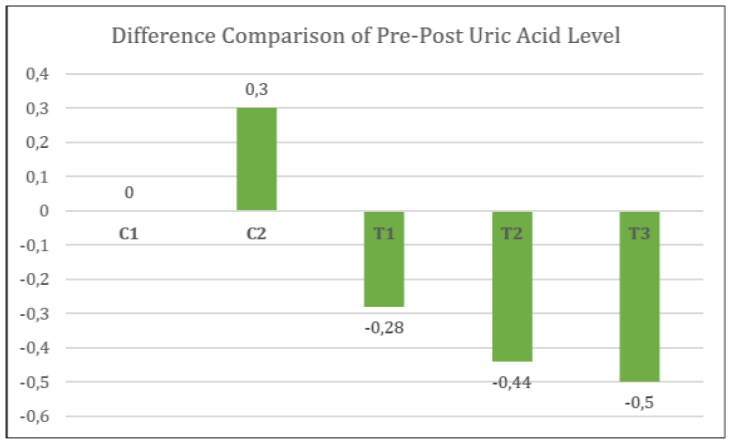

Figure 2. Mean Difference Comparison of PrePost Uric Acid Level Between Groups

The mean difference of uric acid levels between post test and pre-test in $\mathrm{C} 1=0 ; \mathrm{C} 2=0.3$; $\mathrm{T} 1=-0.28 ; \mathrm{T} 2=-0.44$, and $\mathrm{T} 3=-0.5$. From One Way Anova analysis, there was a significant difference of mean difference between groups $(\mathrm{p}=0,001)$. This research showed that the induction by potassium oxonate was able to induce hyperuricemic condition in the treated groups.

To find out the difference in uric acid levels after administration of red ginger powder therapy and lime juice, One Way Anova was tested, and found that there was a significant difference of uric acid level between groups after therapy $(\mathrm{p}<0,001)$.

Table 2.Post Hoc Test results for post uric acid levels

\begin{tabular}{cccccc}
\hline & $\mathrm{C} 1$ & $\mathrm{C} 2$ & $\mathrm{~T} 1$ & $\mathrm{~T} 2$ & $\mathrm{~T} 3$ \\
\hline $\mathrm{C} 1$ & - & $\mathrm{p}=$ & $\mathrm{p}=0.008^{*}$ & $\mathrm{p}=0.304$ & $\mathrm{p}=0.293$ \\
$\mathrm{C} 2$ & & $0.000^{*}$ & & & \\
$\mathrm{~T} 1$ & & & $\mathrm{P}=0.001^{*}$ & $\mathrm{p}=0.000^{*}$ & $\mathrm{p}=0.000^{*}$ \\
$\mathrm{~T} 2$ & & & - & $\mathrm{p}=0.070$ & $\mathrm{p}=0.073$ \\
& & & - & $\mathrm{p}=0.981$ \\
\hline
\end{tabular}

Information: $\mathrm{p}<0.05$; Significant

From table 2 it can be shown that there were significant differences between $\mathrm{C} 2$ and $\mathrm{C} 1$ group ( $\mathrm{p}<0.001), \mathrm{C} 2$ and $\mathrm{T} 1(\mathrm{p}=0.001), \mathrm{C} 2$ and T2 $(\mathrm{p}<0.001)$, C2 with T3 $(\mathrm{p}<0.001)$. The success of red ginger powder therapy and lime juice can also be seen from the difference between pre and post uric acid levels. To determine the difference in uric acid levels based on the pre-and-post data, the KruskalWallis test was performed, and found that there was a significant difference between pre and post test data $(\mathrm{p}=0,001)$. From Mann Whitney test, it was found that there was a significant difference between $\mathrm{C} 2$ and $\mathrm{C} 1$ group $(\mathrm{p}=$ $0.009), \mathrm{C} 2$ and $\mathrm{T} 1(\mathrm{p}=0.009), \mathrm{C} 2$ and $\mathrm{T} 2(\mathrm{p}=$ $0.009), \mathrm{C} 1$ and $\mathrm{T} 3(\mathrm{p}=0.009)$.

\section{DISCUSSION}

This study aimed to determine the uric acid levels of potassium oxonate-induced Wistar rats in the treatment of red ginger powder and lime juice. The results showed that the potassium oxonate induced group had higher uric acid levels than the normal control group. This was in accordance with previous studies stated that injection of potassium oxonate $300 \mathrm{mg} / \mathrm{kgBW}$ in Wistar rats for one hour can increase potassium oxonate levels of uric acid [15]. C1 were induced by potasium oxonate showed an increase of uric acid levels, it can be concluded that potassium oxonate can work more effectively to increase levels gout if induced for more than one hour. Red ginger contains phenolic compounds such as flavonoids, saponins and alkaloids which act as inhibitors of xanthine oxidase so that it can inhibit uric acid formation in the body [16].

High antioxidant content such as gingerol, shagaol and zingerol play a role in capturing reactive oxygen species (ROS) and hydrogen peroxide $\left(\mathrm{H}_{2} \mathrm{O}_{2}\right)$ during the oxidation of the substrate produced by xanthine oxidase (XO) during the process of xanthine metabolism into uric acid so that it can reduce the inflammatory effect [17]. Lime contains citric acid, amino acids, limonen, citric acid, vitamins $\mathrm{C}$ and B1. Flavonoids act as inhibitors of the xanthine oxidase (XO) enzyme so that it can reduce the production of uric acid in the body. Vitamin C is uricosuric enhance the excretion of uric acid through inhibition of its reabsorption by kidney [18].

The results showed that red ginger powder and lime juice had a therapeutic effect in reducing uric acid levels. Negative control groups who were not given any treatment an 
increase in uric acid, while the treatment group was given a combination therapy of red ginger powder with a dose of $300 \mathrm{mg} / 200 \mathrm{gBW}, 600 \mathrm{mg}$ / 200gBW, $1200 \mathrm{mg} / 200 \mathrm{gBW}$ and juice of lime $2 \mathrm{ml} / 150 \mathrm{gBW}$ for two hours can reduce uric acid levels in hyperuricemic Wistar rats. Based on data analysis, all the doses above can significantly reduce uric acid levels but did not find significant differences between groups $\mathrm{T} 1$, $\mathrm{T} 2$, and T3. However, when we observed from the post uric acid level, the difference between the pre-and-post uric acid levels, and from the average $p$ value obtained, the T3 group given a combination of red ginger powder with a dose of $1200 \mathrm{mg} / 200 \mathrm{gBW}$ and $2 \mathrm{ml} / 150 \mathrm{gBW}$ lime juice was the best result.

\section{CONCLUSION}

From this study we can conclude that the combination of red ginger powder and lime juice can reduce uric acid levels in potassium oxonate-induced Wistar rats.

\section{ACKNOWLEDGEMENT}

The authors would like to thank the Ministry of Research Technology and Higher Education of Indonesia for funding this research.

\section{REFERENCES}

1. Dr Tedros Adhanom Ghebreyesus. World Health Statistics 2018 Monitong Health For The SDGs. 2018;15(2):4-8.

2. Kuo CF, Grainge MJ, Zhang W, Doherty M. Global Epidemiology Of Gout: Prevalence, Incidence And Risk Factors. Nat Rev Rheumatol. 2015;11(11):649-62.

3. Riskesdas. Hasil Utama Riskesdas Tentang Prevalensi Diabetes Mellitus di Indonesia 2018. 2018;

4. Purwaningsih T. Faktor-Faktor Risiko Hiperurisemia (Studi Kasus Di Rsu Kardinah Kota Tegal). Univ Diponegoro. 2009;1-3.

5. Bardin T, Richette P. Definition of Hyperuricemia And Gouty Conditions. Curr Opin Rheumatol. 2014;26(2):186-91.

6. Teng GG, And RN, Saag KG.
Pathophysiology, Clinical Presentation And Treatment of Gout. Drugs. 2006;66(12):1547-63.

7. Katzung, G. B. Obat Antiinflamasi Nonsteroid; Obat Antireumatik Pemodifikasi Penyakit, Analgesik Nonopioid, Obat yang digunakan ada Gout dalam Farmakologi Dasar dan Klinik. Edisi ke-1. Jakarta: Penerbit EGC; 2007.

8. Al-azzawie HF, Abd SA. Effects of Crude Flavonoids from Ginger ( Zingiber officinale), on Serum Uric Acid Levels, Biomarkers of Oxidative Stress and Xanthine Oxidase Activity in OxonateInduced Hyperuricemic Rats. Int $\mathrm{J}$ Adv Res. 2015;2(6):55-61.

9. Febriani Y, Riasari H, Winingsih W, Aulifa DL, Permatasari A. The Potential Use of Red Ginger (Zingiber officinale Roscoe) Dregs as Analgesic. Indones J Pharm Sci Technol. 2018;1(1):57-64.

10. Prastiwi SS, Ferdiansyah F. Kandungan dan Aktivitas Farmakologi Jeruk Nipis (Citrus aurantifolia Swing.). Farmaka. 2017;15(2):1-8.

11. Pursriningsih SS, Binar Panunggal. Hubungan Asupan Purin, Vitamin C Dan Aktivitas Fisik Terhadap Kadar Asam Urat Pada Remaja Laki-Laki. J Nutr Coll. 2015;4(1):24-9.

12. Use I, Collection S, History M, Provided M, Notes P, Preparation R, et al. Uric Acid Reagent Set Uric Acid Reagent Set. :5-6.

13. H Kenneth Walker, MD, W Dallas Hall, $\mathrm{MD}$, and $\mathrm{J}$ Willis Hurst $\mathrm{M}$. Clinical Methods: The History, Physical, and Laboratory Examinations. 3rd editio. 1990. 163-170 p.

14. Dahlan MS. Statistik untuk Kedokteran dan Kesehatan: Deskriptif, Bivariat, dan Multivariat. 6th ed. Jakarta: Epidemiologi Indonesia; 2014.

15. Sinaga AF, Bodhi W, Lolo WA. Uji Efek Ekstrak Etanol Daun Salam (Syzygium polyanthum) Terhadap Penurunan Kadar Asam Urat Tikus Putih Diinduksi Potasium Oksonat. J Ilm Farm. 2014;3(2):141-5. 
16. Suciyati SW, Adnyana IK. Red Ginger ( Zingiber officinale Roscoe var rubrum ). Sch Pharmacy, Bandung Inst Technol. 2017;2:60-5.

17. Glantzounis G, Tsimoyiannis E, Kappas A, Galaris D. Uric Acid and Oxidative Stress. Curr Pharm Des. 2005;11(32):4145-51.

18. Giulia Battelli M, Polito L, Bortolotti M, Bolognesi A. Xanthine Oxidoreductase in Drug Metabolism: Beyond a Role as a Detoxifying Enzyme. Curr Med Chem. 2016;23(35):4027-36 